\title{
REPRESENTASI KRISIS EKOLOGI DALAM NOVEL LUKA PEREMPUAN ASAP KARYA NAFI'AH AL-MA'RAB: KAJIAN EKOKRITIK
}

\section{REPRESENTATION OF ECOLOGICAL CRISIS IN NOVEL LUKA PEREMPUAN ASAP BY NAFI'AH AL-MA'RAB: ECOCRITICAL STUDY}

\author{
M. Busairi, Haris Supratno, Tengsoe Tjahyono
}

Universitas Negeri Surabaya

Jalan Lidah Wetan, Lidah Wetan, Kecamatan Lakarsantri, Kota Surabaya, Jawa Timur Ponsel: 085337478346; Pos-el: mbusairi.19003@mhs.unesa.ac.id

\begin{abstract}
Abstrak
Krisis ekologi merupakan fenomena yang penting untuk dikaji agar masyarakat sadar betapa pentingnya menjaga lingkungan. Oleh sebab itu, representasi krisis ekologi dalam novel Luka Perempuan Asap karya Nafi'ah al-Ma'rab merupakan salah satu cara menyadarkan masyarakat untuk menjaga lingkungan. Novel tersebut menggambarkan permasalahan krisis ekologi di Riau, seperti kebakaran hutan, kabut asap, pencemaran, kekeringan, serta pemanasan global sebagai akibat dari pembukaan lahan kelapa sawit. Tujuan penelitian ini untuk mendeskripsikan representasi krisis ekologi dalam novel Luka Perempuan Asap karya Nafi'ah al-Ma'rab. Kajian ekokritik menjadi landasan dasar dalam penelitian krisis ekologi ini. Metode yang digunakan dalam penelitian, yakni deskriptif kualitatif dengan teknik pengumpulan data menggunakan teknik baca dan teknik catat. Langkah-langkah dalam analisis data, yaitu pengumpulan data, reduksi, penyajian, dan penyimpulan data. Adapun hasil penelitian bentuk representasi krisis ekologi dalam novel Luka Perempuan Asap karya Nafi'ah al-Ma'rab yang menggunakan kajian ekokritik ini, yakni (1) krisis ekologi terjadi pada pencemaran tanah dan udara akibat adanya pembakaran hutan yang menimbulkan kabut asap serta tercecernya minyak di area perkebunan kelapa sawit, (2) kerusakan hutan terjadi karena adanya pembukaan lahan kelapa sawit, (3) bencana kekeringan di berbagai daerah karena hutan telah gundul dan minimnya daerah resapan, (4) permukiman penduduk semakin menyempit akibat pembukaan lahan kelapa sawit, (5) pembukaan lahan kelapa sawit mengakibatkan banyak hewan yang punah, dan (6) kondisi bumi semakin panas,
\end{abstract}


tanah mulai kering dan retak, kekurangan sumber air, serta terjadinya kabut asap di mana-mana. Hasil penelitian ini juga menunjukkan bahwa novel Luka Perempuan Asap karya Nafi'ah al-Ma'rab merupakan novel bergenre sastra hijau yang menyampaikan kepedulian terhadap lingkungan alam. Penelitian yang menggunakan pendekatan ekokritik ini menjadi pembelajaran bagi masyarakat tentang pentingnya menjaga lingkungan agar tidak terjadi krisis ekologi. Tidak kalah penting, penelitian ini juga bisa menjadi bahan referensi bagi guru Bahasa dan Sastra Indonesia di sekolah pada pembelajaran analisis teks sastra berbasis lingkungan.

Kata kunci: representasi; krisis ekologi; ekokritik; novel

\begin{abstract}
The ecological crisis is an important phenomenon to be studied so that people are aware of the importance of protecting the environment. Therefore, the representation of ecological crisis in the literary work of the novel Luka Perempuan Asap by Nafi'ah alMa'rab is one way to raise public awareness to protect the environment. The novel describes the problems of the ecological crisis in Riau such as forest fires, smog, pollution, drought, and global warming due to oil palm land clearing. The purpose of this study is to describe the representation of the ecological crisis in the novel Luka Perempuan Asap by Nafi'ah al-Ma'rab. Ecocritical studies become the basic foundation in this ecological crisis research. The method used in this research is descriptive qualitative with data collection techniques using reading techniques and note-taking techniques. The steps in data analysis are, data collection, reduction, presentation, and data inference. The results of the research on the form of representation of the ecological crisis in the novel Luka Perempuan Asap by Nafi'ah al-Ma'rab using an ecocritical study, it can be concluded that (1) ecological crisis occurs in soil and air pollution due to forest fires that cause smog and oil spills in oil palm plantation areas, (2) forest damage occurs due to the clearing of oil palm land, (3) drought disasters in various areas because the forests have been deforested and the lack of infiltration areas, (4) population settlements are getting narrower due to oil palm land clearing, (5) the clearing of oil palm land has resulted in the extinction of many animals, and (6) the earth's condition is getting hotter, the soil is dry and cracked, lack of water sources, and the occurrence of smog everywhere. The results of this study also show that the novel Luka Perempuan Asap by Nafi'ah al-Ma'rab is a novel with the green literary genre in conveying concern for the natural environment. This research with an ecocritical approach is a lesson for the community about the importance of protecting the environment so that an ecological crisis does not occur as well as being a reference material for Indonesian Language and Literature teachers in schools in learning environmental-based literary text analysis.
\end{abstract}

Keywords: representation; ecological crisis; ecocritic; novel 


\section{Pendahuluan}

Beberapa tahun terakhir krisis ekologi sudah sangat memprihatinkan. Banyak ancaman terhadap masa depan yang perlu diperhatikan oleh manusia agar dapat dicegah. Populasi manusia di muka bumi yang setiap tahun semakin bertambah tentu sangat memengaruhi keadaan lingkungan. Populasi manusia yang semakin bertambah tersebut berpotensi merusak alam sekitar tanpa melihat dampak yang akan ditimbulkan. Kondisi seperti itu cenderung memunculkan berbagai krisis lingkungan, seperti perubahan iklim, bencana alam, pencemaran (pencemaran udara, air, dan tanah), penggusuran tempat tinggal, kekurangan air bersih, maupun kepunahan flora dan fauna.

Terkait semakin banyaknya kerusakan lingkungan, khususnya di Indonesia, perlu adanya perhatian semua kalangan, tidak terkecuali pengarang. Sebagai bagian dari anggota masyarakat, pengarang tidak menutup telinga dan mata melihat alam yang semakin rusak. Hal itu kemudian dituangkan menjadi sebuah karya yang kemudian dibaca oleh masyarakat. Masyarakat yang membaca hasil karya tersebut diharapkan dapat memperoleh pemahaman tentang berbagai permasalahan lingkungan serta solusi seperti apa yang harus dilakukan agar tidak terjadi kerusakan lingkungan.

Salah satu karya yang berbicara tentang kerusakan lingkungan adalah novel Luka Perempuan Asap karya Nafi'ah al-Ma'rab. Novel yang bertemakan lingkungan ini sangat mewakili krisis ekologi yang terjadi di Indonesia. Pengarang sangat piawai menggambarkan berbagai permasalahan krisis ekologi di lingkungan perkebunan sawit di Riau, seperti kebakaran hutan, kekurangan sumber mata air, serta adanya duka berhari-hari dalam menghadapi bencana kabut asap yang berkepanjangan.

Berkaitan dengan krisis ekologi dalam sebuah karya sastra, terdapat bidang kajian baru dari para kritikus sastra. Kajian baru tersebut dikenal dengan istilah ekokritik, yakni kajian kritik sastra yang mengkaji permasalahan lingkungan yang terdapat dalam karya sastra. Ekokritik dapat memberikan perhatian bagaimana keterkaitan timbal balik antara karya sastra dan lingkungan. Dalam hal ini ekokritik sebagai disiplin ilmu yang mengkaji tentang hubungan sastra dengan lingkungan dan ilmu sastra tersebut sebagai pusat pendekatan (Endraswara, 2016a, p. 17). Kajian ekokritik ini dapat memberikan berkontribusi berkaitan dengan masalah 
lingkungan dan dapat membantu mengeksplorasi, mendefinisikan, serta dapat menyelesaikan masalah krisis ekologi (Endraswara, 2016b, p. 33). Oleh karena itu, kajian ekokritik berlandaskan pada penelitian yang terkait dengan representasi gagasan, sikap, serta tanggapan masyarakat pada lingkungan, termasuk juga nilai kearifan lingkungan.

Cerita dalam novel Luka Perempuan Asap karya Nafi'ah al-Ma'rab sangat merepresentasikan krisis ekologi di Indonesia. Hal itulah yang menjadikan penulis tertarik untuk melakukan pengkajian menggunakan pendekatan ekokritik yang dikemumukakan oleh Greg Garrard.

Beberapa alasan penulis melakukan pengkajian ekokritik terhadap novel tersebut sebagai berikut. Pertama, novel Luka Perempuan Asap karya Nafi'ah alMa'rab membahas kepedulian serta kritikan terhadap kerusakan lingkungan. Selain itu, permasalahan antartokoh dalam novel memiliki keterkaitan khusus dengan alam dan lingkungan. Kedua, permasalahan ekologi yang ada dalam novel Luka Perempuan Asap karya Nafi'ah al-Ma'rab bukan hanya masalah kerusakan alam, tetapi juga masalah ekologi manusia dengan lingkungan di daerah Riau. Ketiga, novel Luka
Perempuan Asap karya Nafi' ah al-Ma'rab merupakan kritik sosial terhadap permasalahan ekologi kehidupan seharihari sehingga persoalan manusia dan lingkungan di daerah Riau pada novel tersebut merupakan bentuk kritik pengarang terhadap permasalahan ekologi di Indonesia. Keempat, pemilihan kajian ekokritik mampu menganalisis sastra dari perspektif lingkungan sehingga cocok untuk novel Luka Perempuan Asap karya Nafi'ah al-Ma'rab yang berwawasan ekologi. Pengkajiannya dilakukan dengan menggunakan pendekatan ekokritik.

Tulisan terkait kajian ekokritik yang merupakan kajian sastra mutakhir sudah mulai banyak dilakukan, baik terhadap film, puisi, drama, cerpen, maupun novel. Penelitian terdahulu tentang ekokritik pernah dilakukan Kharismadani (2020) yang meneliti tentang representasi kerusakan lingkungan serta dampak yang ditimbulkan dalam novel Altitude 367 Takhta Mahameru. Penelitian deskriptif kualitatif yang menggunakan metode dokumentasi serta teknik membaca dan mencatat objek tersebut menghasilkan simpulan bahwa kerusakan lingkungan berasal dari manusia. Kerusakan tersebut meliputi pencemaran tanah, kerusakan hutan, dan kepunahan keanekaragaman hayati. Adapun dampak yang ditimbulkan 
akibat kerusakan lingkungan meliputi menyusutnya air danau, berkurangnya lahan produktif, dan kerusakan ekosistem.

Berikutnya penelitian dilakukan Ritmadanti (2019) yang meneliti persoalan ekologis dan bagaimana penyelamatan lingkungan dalam novel Kesturi dan Kepodang Kuning Karya Afifah Afra. Penelitian yang menggunakan teori ekokritik Greg Garrard tersebut menggunakan metode kualitatif dengan pencatatan dan pembacaan sebagai teknik pengumpulan datanya. Dari hasil penelitian tersebut disimpulkan bahwa masalah ekologi yang terjadi, antara lain penggusuran perumahan/tempat tinggal, kepunahan binatang, dan pembabatan hutan. Hal ini terjadi akibat ulah manusia dan kurangnya pengetahuan ekologis masyarakat. Adapun upaya penyelamatan kerusakan lingkungan dalam novel tersebut dilakukan oleh anggota LSM yang melakukan penyuluhan, diskusi publik, melakukan aksi penghijauan, serta membuat dokumenter tentang burung kepodang.

Beberapa penelitian di atas memiliki beberapa persamaan dengan penelitian ini, yakni sama-sama menggunakan pendekatan ekokritik, metode kualitatif, serta teknik membaca dan mencatat.
Sementara itu, perbedaannya terletak pada fokus penelitian terkait krisis ekologi. Berdasarkan hal tersebut, maka judul penelitian ini adalah Representasi Krisis Ekologi dalam Novel Luka Perempuan Asap Karya Nafi'ah al-Ma'ra. Adapun tujuan dari penelitian ini adalah untuk mengetahui dan mendeskripsikan representasi krisis ekologi dalam novel Luka Perempuan Asap karya Nafi'ah alMa'rab. Penelitian ini diharapkan bermanfaat sebagai referensi penelitian berikutnya yang berkaitan dengan krisis ekologi dan ekokritik. Bagi siswa dan guru diharapkan penelitian ini sebagai bahan referensi dalam mempelajari analisis karya sastra lebih khususnya novel.

\section{Landasan Teori}

Penggunaan teori dalam artikel ini merupakan syarat dan pedoman penulis untuk menentukan arah penulisan dan kualitas karya yang ditulis. Penulisan artikel ini bersumber dari hasil penelitian serta buku dengan menggunakan beberapa landasan teori yang berkaitan dengan topik penelitian. Adapun Landasan teori sebagai berikut.

\subsection{Ekokritik}

Karya sastra merupakan media representasi dari lingkungan sekitar yang 
bisa digunakan sebagai kritik terhadap apa yang telah terjadi. Salah satu disiplin ilmu sastra yang termasuk kajian sastra mutakhir adalah ekokritik. Ekokritik merupakan kajian yang meneliti hubungan sastra dengan lingkungan, baik lingkungan manusia maupun nonmanusia. Istilah ekokritik berasal dari bahasa Inggris ecocriticism yang merupakan bentukan dari kata ecology dan kata criticism. Ekologi dapat didefinisikan sebagai studi ilmiah tentang pola hubungan timbal balik antara manusia, hewan, tumbuhan dan lingkungannya. Kritik dapat diartikan sebagai bentuk evaluasi dan ekspresi dari sesuatu. Oleh karena itu, ekokritik dapat diartikan sebagai kritik sastra yang berwawasan lingkungan (Harsono, 2008).

Kajian ekokritik merupakan kajian multidisiplin. Di satu sisi menggunakan teori sastra, di sisi lain menggunakan teori ekologi. Dengan demikian, kombinasi kedua disiplin tersebut melahirkan ekokritik. Sudikan (2016) mengatakan bahwa sastra dan lingkungan alam merupakan dua hal yang selalu dekat dan mempunyai hubungan timbal balik. Banyak pengarang (sastrawan) yang memanfaatkan alam sebagai latar atau objek dalam penciptaan karya sastra, seperti hutan, gunung, laut, hewan, dan lain-lain. Hal inilah yang membuat kajian ekokritik semakin banyak dikaji dalam berbagai jenis karya sastra.

Terkait hubungan sastra dengan lingkungan, Glotfelty (1996) mengatakan bahwa ekokritik adalah studi tentang hubungan sastra dengan lingkungan fisik yang berpusat bumi. Hubungan sastra dengan lingkungan akan berdampak baik bagi kehidupan karena dapat menginspirasi pembaca dan memberikan kritik terhadap lingkungan melalui karya sastra. Pendapat lain mengatakan bahwa ekokritik adalah kajian sastra yang mengeksplorasi bagaimana manusia membayangkan serta menggambarkan hubungan manusia dengan lingkungan (Garrard, 2012). Berdasarkan beberapa pendapat tersebut dapat disimpulkan bahwa ekokritik merupakan kajian mutakhir dalam disiplin sastra yang mengkaji dan mengkritik lingkungan (ekologi) melalui karya sastra.

Kajian ekokritik memiliki fokus kajian khusus, sama seperti disiplin lainnya. Adapun fokus kajian ekokritik menurut Endraswara (2016a), yakni 1) mengkaji seluk-beluk lingkungan yang dapat membentuk atau memengaruhi cita sastra, ini menjadi bagian ekologi sastra; 2) mengkaji lingkungan yang dijelaskan dalam karya sastra, lalu disebut sastra 
ekologis; 3) mengkaji resepsi lingkungan terhadap karya sastra berbasis ekologi, lalu dinamakan sebagai resepsi sastra ekologi. Ketiga fokus kajian ini dapat diteliti secara bersamaan ataupun terpisah sesuai kebutuhan. Ketiga fokus kajian ekokritik tersebut yang jelas selalu ada konteks ekologi.

\subsection{Representasi}

Representasi berasal dari bahasa Inggris yang artinya perwakilan atau penggambaran. Representasi merupakan istilah yang berkembang dalam karya sastra dan terkait dengan pandangan atau kepercayaan bahwa karya sastra sebenarnya adalah gambaran atau tiruan dari realitas kehidupan. Dalam konteks ini, sastra dianggap sebagai gambaran realitas simbolik (Teeuw, 1984). Karya sastra merupakan bagian dari seni yang bersumber dari masyarakat. Sumber yang dimaksud ialah fakta sosial dan lingkungan alam. Fakta-fakta yang ada disesuaikan dengan kehidupan masyarakat, dengan selalu mengaitkan keberadaannya dengan fakta sosial lainnya (Ratna, 2003).

Secara sederhana, representasi diartikan sebagai gambaran tentang halhal tertentu dalam kehidupan melalui media yang dalam hal ini karya sastra. Menurut Hall (dalam Nirwana, 2020), representasi menghubungkan konsep dengan menggunakan bahasa yang memungkinkan kita untuk menafsirkan benda, orang, peristiwa, dan dunia fiksi dari benda, orang, dan peristiwa tidak nyata. Representasinya dapat berupa kata, kalimat atau bahasa, gambar, cerita, dan bentuk lain yang mewakili pikiran, fakta, emosi, dan lain-lain. Pendapat lain juga mengatakan bahwa representasi bergantung pada simbol dan gambar yang ada dan dapat dipahami secara budaya sebagai pesan dan simbol atau teks secara timbal balik (Hartley, 2020).

Representasi yang terdapat dalam karya sastra merupakan ekspresi bahasa oleh pengarang melalui simbol-simbol tertulis dan pembaca harus bisa menafsirkannya. Ekspresi bahasa tersebut sebagai representasi dari realitas sosial dan lingkungan alam sekitar. Realitas semacam ini membutuhkan pengkajian lebih dalam lagi terkait gagasan pengarang dalam karya sastra.

Karya sastra tidak hanya mencerminkan fenomena individu, tetapi lebih dari itu juga mengidentifikasi, memahami tingkah laku kelompok masyarakat, serta merekam perubahan sosial dan lingkungan alam sekitar (Leni, R. E., Surbakti, A., \& Nasution, 2015). Oleh karena itu, sastra merupakan cermin 
masyarakat. Berdasarkan pernyataan di atas dapat disimpulkan bahwa representasi adalah perwakilan atau penggambaran suatu objek yang berkaitan dengan gagasan yang kita sampaikan melalui bahasa tertulis dan lisan, simbol, maupun tanda yang berasal dari kenyataan.

\subsection{Krisis Ekologi}

Fenomena kerusakan lingkungan beberapa tahun terakhir semakin banyak terjadi, misalnya kebakaran hutan, kekeringan, kabut asap, pencemaran (air, tanah, dan udara), kekurangan air bersih, penebangan hutan, kepunahan hewan, dan masih banyak lagi. Dilihat dari fenomena tersebut, sebagian besar ancaman yang kita hadapi saat ini tampaknya bukan berasal dari ancaman eksternal atau "bersifat natural", tetapi disebabkan oleh aktivitas manusia. Bersamaan dengan itu, alasan munculnya berbagai ancaman di muka bumi, seperti berbagai konsekuensi ekologis, diakibatkan oleh perkembangan kegiatan industri yang tidak terkendali atau teknologi rekayasa genetika (Mudhoffir, 2011).

Krisis ekologi global yang semakin serius dewasa ini telah menjadi pusat masalah dunia. Dampak krisis ekologi telah dirasakan oleh orang-orang di seluruh dunia. Tidak hanya negara maju, negara berkembang dan negara miskin juga merasakan hal yang sama. Ancaman bahaya dan bencana yang akan segera terjadi dapat menghancurkan peradaban manusia setiap saat. Hal itu akan sulit dikendalikan karena disebabkan oleh keserakahan manusia. Ini terjadi karena kerusakan lingkungan, penggunaan alam yang berlebihan, dan penggunaan teknologi yang tidak ramah lingkungan serta faktor lainnya.

Istilah krisis ekologi berakar dari dua kata, yaitu "krisis" dan "ekologi". Kata krisis dalam Kamus Besar Bahasa Indonesia memiliki banyak arti, diantaranya keadaan yang genting, keadaan yang berbahaya, dan keadaan suram. Sementara itu, ekologi berarti hubungan timbal balik antara makhluk hidup dan kondisi alam sekitarnya (KBBI, 2016). Menurut Salim (dalam Syamsudin, 2017), ekologi berasal dari bahasa Yunani oikos dan logo. Kata oikos berarti tempat tinggal beserta segala penghuninya, sedangkan logo berarti ajaran, pengetahuan, dan ilmu. Secara etimologi ekologi berarti pengetahuan mengenai cara untuk mengatur tempat tinggal. Adapun istilah terminologi ekologi adalah ilmu yang mempelajari makhluk hidup, bukan sebagai unit terpisah, tetapi sebagai anggota 
serangkaian makhluk hidup yang berinteraksi dan berhubungan serta memiliki fungsi dan peran di lingkungan kehidupan. Dengan demikian, ekologi merupakan suatu ilmu mengenai hubungan antara hewan, manusia, dan lingkungannya serta keseimbangan antara hubungan tersebut. Oleh karena itu, ekologi menitikberatkan pada unsurunsur hubungan antara masing-masing organisme dengan lingkungan sekitarnya.

Isu krisis ekologi merupakan salah satu dari isu global yang penting dibahas dan dicarikan solusinya selain dari isu lainnya seperti demokrasi dan hak asasi manusia (Keraf, 2010). Terkait hal tersebut, krisis ekologi dapat juga dikaitkan dengan karya sastra yang di dalamnya pengarang memasukkan unsur ekologi dengan mengkritisi fenomena yang terjadi terkait krisis ekologi. Masalah krisis ekologi jelas sangat berbeda dengan masalah non-ekologis. Keaktifan manusia dalam merespons masalah krisis ekologi akan menentukan ekosistem lingkungan masa depan.

Terkait krisis ekologi, Garrard dalam bukunya menjelaskan terkait konsep ekokritik yang menjadi landasan peneliti tentang representasi krisis ekologi. Garrard (2012) menjelaskan ada 6 konsep, yaitu 1) pencemaran, 2) hutan, 3) bencana, 4) tempat tinggal, 5) binatang, dan 6) bumi.

\section{Metode Penelitian}

Penelitian ini menggunakan metode kualitatif dengan jenis pendekatan deskriptif. Penggunaan pendekatan deskripsi dimaksudkan untuk mendeskripsikan data terkait fenomena representasi krisis ekologi dalam novel Luka Perempuan Asap karya Nafi'ah alMa'rab. Selanjutnya, data penelitian ini berupa tuturan atau dialog yang memuat fenomena representasi krisis ekologi dalam novel Luka Perempuan Asap karya Nafi'ah al-Ma'rab. Sumber data penelitian ini adalah novel Luka Perempuan Asap karya Nafi'ah al-Ma'rab yang diterbitkan oleh Tiga Serangkai tahun 2017 dengan jumlah halaman sebanyak 264 halaman. Teknik pengumpulan data penelitian ini adalah teknik baca dan teknik catat. Hasil akhir penelitian ini didapatkan melalui empat tahap teknik analisis data, yaitu pengumpulan data, reduksi, penyajian, dan penyimpulan data.

\section{Pembahasan}

Makalah ini bebentuk deskriptif kualitatif guna mendeskripsikan teksteks sesuai dengan rumusan masalah 
yang diteliti terkait fenomena representasi krisis ekologi dalam novel Luka Perempuan Asap karya Nafi'ah alMa'rab. Berdasarkan hasil penelitian yang telah dilakukan, terdapat 52 data representasi krisis ekologi dalam novel Luka Perempuan Asap karya Nafi'ah al-Ma'rab, yakni pencemaran 3 data, hutan 6 data, bencana 24 data, tempat tinggal 3 data, hewan 3 data, dan bumi 13 data. Untuk lebih jelasnya akan diuraikan data representasi krisis ekologi yang mewakili hasil penelitian.

\subsection{Pencemaran}

Data 1

"Tidak ada yang aneh. Tapi orang-orang kota begitu penasaran melihat tajamnya duri pelepah sawit, melihat brondolan yang jatuh ke tanah dalam kemuning, dan minyaknya tercecer di manamana" (Al-Ma'rab, 2017, p. 100).

Data 1 menunjukkan krisis ekologi mengenai pencemaran. Dalam novel tersebut diceritakan bahwa Mun dan anggota peneliti lainnya, $\mathrm{Bu}$ Wilda, mengunjungi daerah tempat tinggal Mun. Tujuan mereka untuk melihat kondisi perkebunan sawit. Setelah observasi, Mun dan peneliti melihat banyak brondolan yang jatuh dan minyak tercecer di manamana, tetapi Mun sudah terbiasa melihat hal itu terjadi. Representasi pencemaran minyak yang tercecer tersebut menggambarkan bagaimana tanah telah tercemar oleh minyak. Dalam kondisi seperti ini telah terjadi pencemaran tanah yang disebabkan oleh para petani sawit. Pencemaran tanah tidak hanya dari minyak, bisa juga terjadi dari pembuangan limbah anorganik, pestisida, limbah industri, maupun limbah dari rumah tangga.

\section{Data 2}

"Kuabadikan api yang menjulang tinggi dengan asap yang tebal" (Al-Ma'rab, 2017, p. 103).

Data 2 menunjukkan pencemaran udara akibat pembakaran lahan oleh orang yang tidak bertanggung jawab. Mereka sengaja membakar lahan agar bisa membuka lahan untuk menanam kelapa sawit. Dalam cerita dijelaskan bahwa orang-orang juga dibayar dengan upah besar untuk membakar lahan tersebut. Api yang terus berkobar menimbulkan asap yang tebal di manamana sehingga orang-orang di kampung mengungsi. Hal seperti ini pun terjadi di kota karena asap sudah menyebar sampai ke kota. Suasana pun menjadi putih semua akibat kabut asap yang tebal serta jarak pandang pun hanya beberapa meter. 


\subsection{Hutan}

\section{Data 3}

"Kemarin lahan sawitnya sudah mulai dibuka. Tapi karena cuaca lagi panas, jadi lebih baik kita pilih pembakaran saja" (Al-Ma'rab, 2017, p. 144).

Data 3 menunjukkan representasi krisis ekologi hutan belantara. Lahan baru yang dibuka tersebut merupakan hasil dari proses pembakaran oleh pihak yang tidak bertanggung jawab. Pembakaran dilakukan agar proses penanaman bibit sawit bisa lebih cepat. Cuaca sangat panas membuat lahan cepat terbakar. Kondisi ini memungkinkan adanya bencana lain, yaitu pencemaran udara yang membuat daerah sekitar lahan bahkan daerah lain pun ikut tercemar akibat kabut asap dari hasil pembakaran lahan.

\section{Data 4}

"Ini semua ulah orangorang tamak yang membakar hutan. Mereka hendak meluaskan kebun-kebun hingga merusak lingkungan" (AlMa'rab, 2017, p. 159).

Data 4 menunjukkan representasi krisis ekologi hutan belantara. Hutan yang seharusnya menjadi pelindung bumi justru menjadi musuh manusia. Manusia tamak yang hanya peduli pada keuntungan cenderung menghalalkan segala cara untuk mendapatkan keuntungan. Manusia yang tamak tidak memikirkan konsekuensi yang disebabkan oleh pembakaran hutan. Industri kelapa sawit saat ini merupakan industri yang strategis karena terkait sektor pertanian yang sedang berkembang di banyak negara daerah tropis, seperti Indonesia dan Malaysia. Keadaan ini menunjukkan bahwa perkebunan kelapa minyak sawit saat ini menghasilkan pertumbuhan

ekonomi yang sangat pesat. Namun, tidak ada upaya untuk melindungi keseimbangan lingkungan dan ekosistem perkebunan oleh pihak pemerintah yang bertanggung jawab.

\subsection{Bencana}

\section{Data 5}

"Kemarau panjang telah membuat pucuk-pucuk bunga sawit enggan tumbuh. Buah tak ada karena keringnya tanah di perkebunan" (Al-Ma'rab, 2017, p. 142)

Data 5 menunjukkan bencana kekeringan atau kemarau. Dalam cerita digambarkan bahwa alam sudah tidak lagi bersahabat dengan manusia. Kekeringan atau kemarau jangka panjang disebabkan oleh pembakaran lahan yang sedang terjadi untuk pembukaan lahan sawit baru. Perubahan iklim ini juga ditandai dengan sumber air sudah berkurang, suhu 
meningkat dari biasa, serta hujan tak kunjung turun. Hal ini mengakibatkan hanya sedikit pohon sawit yang berbuah akibat kekurangan air. Ini membuat para petani sawit rugi ditambah harga jual kelapa sawit dengan harga di bawah normal.

\section{Data 6}

"Pagi mulai memutih, bukan karena tertutup embun, tapi jerebu yang mengapung di udara. Hari seolah selalu mendung, di langit-langit yang tampak hanya putih dan kemuning. Langit yang biru telah hilang, hari-hari mulai suram. Pagi yang semula menyajikan kesejukan, kini berubah menjadi kesesakan" (Al-Ma'rab, 2017, p. 236).

Data 6 menunjukkan bencana kabut asap. Hal ini terjadi akibat banyaknya lahan-lahan kosong yang sengaja dibakar untuk membuka lahan sawit yang baru. Di tambah lagi bencana lain seperti kekeringan yang membuat api semakin berkobar dan asap semakin tebal. Langitlangit tampak semakin memutih dan membuat seluruh aktvitas masyarakat terganggu. Selain itu, adanya bencana kabut asap yang tidak sedikit mengakibatkan adanya korban jiwa.

\subsection{Tempat Tinggal}

\section{Data 7}

"Perjalanan melalui perkebunan sawit yang hijau dengan bukit-bukit yang naik turun. Tanah-tanah berwarna merah terbentang di sepanjang jalan. Rumah-rumah penduduk masih jarang dan hanya sesekali saja melalui kawasan perkotaan" (Al-Ma'rab, 2017, p. 99).

Data 7 menunjukkan bagaimana permukiman warga atau tempat tinggal yang belum disentuh warga kampung dijadikan sebagai lahan sawit. Dalam novel diceritakan Mun bersama Bu Wilda selaku dosen pembimbing skripsi sekaligus menjadi teman penelitian, terjun bersama di lapangan dalam rangka mengobservasi serta mewawancarai para petani atau pekerja di perkebunan kelapa sawit. Dalam perjalanan ke lapangan masih terdapat lahan hijau berbukit yang belum terjamah dan belum dijadikan kawasan pembukaan lahan baru. Hal ini tentu sangat baik karena tidak dibukannya lahan baru akan mengurangi kegiatan pembakaran lahan. Dengan begitu secara otomatis akan mengurangi adanya bencana kabut asap.

\section{Data 8}

"Di bagian sebelah utara sedang ada proyek pembukaan lahan untuk kebun yang lebih luas lagi, Ibu bisa sekalian lihat ke sana" (Al-Ma'rab, 2017, p. 101).

Data 8 menunjukkan bagaimana daerah yang kosong sudah dibuka sebagai 
lahan baru untuk menanam kelapa sawit.

Pembukaan lahan yang lebih luas tentunya dibarengi pembakaran lahan. Di dalam cerita digambarkan bagaimana para petani kelapa sawit yang membuka lahan baru memilih membakar lahan yang kering dengan upah yang besar. Hal ini tentu akan menjadi masalah karena selain adanya bencana asap, akan ada daerah permukiman yang berkurang. Selain itu, hewan-hewan yang ada akan punah serta tumbuhan lain pun ikut mati.

\subsection{Hewan \\ Data 9}

"Suasana sepi, hanya ada suara binatang-binatang yang sayupsayup terdengar" (Al-Ma'rab, 2017, p. 102).

Data 9 menunjukkan bahwa hewanhewan yang ada di malam hari, seperti jangkrik, burung, kodok, dan lainnya mulai punah. Suara yang biasanya terdengar jelas malam hari mulai sayupsayup. Hewan-hewan tersebut biasanya ada di semak-semak maupun pohon sebagai tempat bertenggernya burung serta hewan lainnya. Namun, dengan adanya kekeringan serta pembakaran lahan dan hutan, keadaan hewan tersebut mulai menyusut.

\section{Data 10}

"Bahkan, sebagian telah retak.

Tak ada lagi kolam yang berair.

Ikan-ikan lesap entah ke mana" (Al-Ma'rab, 2017, p. 138).
Data 10 menunjukkan hewan air yang mulai punah. Dalam novel diceritakan bahwa musim panas yang sudah lama terjadi di daerah tempat tinggal Mun. Hal ini dikarenakan banyak daerah yang telah dibakar secara sengaja untuk kepentingan membuka lahan sawit. Kondisi ini pun diperparah dengan tidak adanya hujan sehingga aliran air baik di sungai maupun di danau mulai kering. Orang-orang di kampung ataupun anakanak yang biasa mencari ikan sudah tak lagi ke sungai karena ikan-ikan telah lesap entah kemana.

\subsection{Bumi}

Data 11

"Semua tempat telah rata menjadi putih. Hingga ke sudutsudut ruangan rumah, tak ada lagi yang tersisa. Oksigen seolah sirna bersama kepulan putih di udara yang bercampur dengan warna kuning belerang sisa pembakaran" (Al-Ma'rab, 2017, p. 159).

Data 11 menunjukkan bagaimana dampak kebakaran lahan dan asap yang semakin banyak mengepul di atas langit. Kondisi seperti itu menyebabkan oksigen sudah tidak lagi sehat untuk dihirup. Dalam cerita tersebut kepulan asap sudah tersebar di setiap sudut ruangan dan kampung. Kondisi lingkungan sudah berwarna putih tebal dan jarak pandang pun hanya beberapa meter. Hal tersebut 
menjadi krisis ekologi yang terus terjadi setiap pembukaan lahan baru atau awal musim kemarau. Itulah yang menyebabkan orang-orang yang ada di kampung tersebut memilih mengungsi ke daerah tetangga akibat kabut asap yang terus terjadi. Selain itu, ada banyak korban jiwa maupun yang dirawat di rumah sakit akibat peristiwa tersebut.

\section{Data 12}

"Bumi yang dulu berkah kini telah memerah, memanas, dan mengering hingga nyaris membunuh siapa saja" (AlMa'rab, 2017, p. 239).

Data 12 menunjukkan bagaimana dampak dari adanya pembukaan lahan baru untuk tanaman kelapa sawit. Keadaan bumi sudah tak seperti sediakala, lingkungan sudah menjadi panas, serta tanah mulai kering dan retak. Sumber air mengalami kekurangan, ditambah lagi adanya pembakaran lahan yang menyebabkan kabut asap di mana-mana.

\section{Penutup}

Berdasarkan hasil penelitian dan pembahasan dapat disimpulkan bahwa novel Luka Perempuan Asap karya Nafi'ah al-Ma'rab memiliki konsepkonsep sastra ekologis yang meliputi pencemaran, hutan belantara, bencana, tempat tinggal, hewan, dan bumi.
Konsep sastra ekologis tersebut mengambarkan representasi krisis ekologi yang menunjukkan bahwa (1) krisis ekologi terjadi pada pencemaran tanah dan udara akibat adanya pembakaran hutan yang menimbulkan kabut asap serta tercecernya minyak di area perkebunan kelapa sawit; (2) kerusakan hutan terjadi karena adanya pembukaan lahan kelapa sawit; (3) bencana kekeringan di berbagai daerah karena hutan telah gundul dan minimnya daerah resapan;

permukiman penduduk semakin menyempit akibat pembukaan lahan kelapa sawit; (5) pembukaan lahan kelapa sawit mengakibatkan banyak hewan yang punah; dan (6) kondisi bumi semakin panas, tanah mulai kering dan retak, kekurangan sumber air, serta terjadinya kabut asap dimana-mana.

Berdasarkan penelitian ini, masyarakat bisa tersadar betapa pentingnya menjaga lingkungan agar tidak terjadi berbagai masalah ekologis yang dapat merugikan masyarakat sendiri. Hasil penelitian ini juga menunjukkan bahwa novel Luka Perempuan Asap karya Nafi'ah al-Ma'rab merupakan novel yang bergenre sastra hijau dalam menyampaikan kepedulian terhadap lingkungan alam. Selain itu, penelitian ini menjadi bahan referensi bagi guru Bahasa 
dan Sastra Indonesia di sekolah pada pembelajaran analisis teks sastra berbasis lingkungan.

\section{Daftar Pustaka}

Al-Ma'rab, N. 2017. Luka Perempuan Asap. Solo: Tiga Serangkai.

Endraswara, S. 2016a. Ekokritik Sastra: Konsep Teori dan Terapan. Yogyakarta: Morfalingua.

Endraswara, S. 2016b. Metode Penelitian Ekologi Sastra. Yogyakarta: CAPS (Center for Academic Publishing Service).

Garrard, G. 2012. Ecocriticism (Second Edi). London and New York: Routledge.

Glotfelty, C. dan H. F. 1996. The Ecocriticism Reader Landmarks in Literary Ecology.

Harsono, S. 2008. Ekokritik: Kritik Sastra Berwawasan Lingkungan. Kajian Sastra, 32(1), 31-50. Retrieved from https://ejournal.undip.ac.id

Hartley, J. 2020. Communication, cultural and media studies: The key concepts (fifth edit). London: Routledge.

KBBI. 2016. KBBI (Kamus Besar Bahasa Indonesia). Retrieved February 14, 2021 , https://kbbi.kemdikbud.go.id/ from

Keraf, A. S. 2010. Etika Lingkungan Hidup. Jakarta: Nusantara, PT Kompas Media.
Kharismadani, Juanda, H. 2020. Representasi Alam dalam Novel Altitude 3676 Takhta Mahameru Karya Azzura Dayana: Tinjauan Ekokritik. Neologia: Jurnal Bahasa Dan Sastra Indonesia, 1(1), 36-45. Retrieved from http://ojs.unm.ac.id/neologia

Leni, R. E., Surbakti, A., \& Nasution, S. N. 2015. Representasi Masyarakat Pincalang Menghadapi Era Modernisasi Dalam Novel Pincalang Karya Idris Pasaribu. Jurnal Kajian Linguistik, 12(1), 138-160. Retrieved from https://bit.ly/39SC0KT

Mudhoffir, A. M. 2011. Krisis Ekologi dan Ancaman bagi Kapitalisme. MASYARAKAT: Jurnal Sosiologi, 16(1), 93-102. https://doi.org/10.7454/mjs.v16i1.4 874

Nirwana, R. S. E. 2020. Representasi Kesadaran Budaya Lokal Perupa Dalam Penciptaan Karya Seni dan Desain di Era Kontemporer. Pasuruan: Qiara Media.

Ratna, N. K. 2003. Sastra dan sejarah: Rekonstruksi fiksional dan faktual. Surakarta: FSSR UNS.

Ritmadanti Ariputri, Juanda, S. S. S. 2019. Persoalan Ekologis dalam Novel Kesturi dan Kepodang Kuning Karya Afifah Afra: Suatu Kajian Ekokritik Greg Garrard (Universitas Negeri Makassar). Retrieved from http://eprints.unm.ac.id/id/eprint/13 739

Sudikan, S. Y. 2016. Ekologi Sastra. Lamongan: CV. Pustaka Ilalang Group. 
Representasi Krisis Ekologi...

Syamsudin, M. 2017. Krisis Ekologi Global Dalam Perspektif Islam. Jurnal Sosiologi Reflektif, 11(2), 83. https://doi.org/10.14421/jsr.v11i2.1 353

Teeuw, A. 1984. Sastra dan Ilmu Sastra: Pengantar Teori Sastra. Jakarta: Dunia Pustaka Jaya. 